\title{
Search for Stability under Price Risk
}

\author{
Andrew Schmitz \\ Department of Food and Resource Economics, University of Florida, Gainesville, USA \\ Email: aschmitz@ufl.edu
}

How to cite this paper: Schmitz, A. (2021) Search for Stability under Price Risk. Theoretical Economics Letters, 11, 674-679. https://doi.org/10.4236/tel.2021.114044

Received: May 24, 2021

Accepted: July 23, 2021

Published: July 26, 2021

Copyright () 2021 by author(s) and Scientific Research Publishing Inc. This work is licensed under the Creative Commons Attribution International License (CC BY 4.0).

http://creativecommons.org/licenses/by/4.0/

\begin{abstract}
Society's preference for commodity price stability brought about by storage is supported by many researchers. However, most of the models assume that both prices and quantities are known with certainty. Also, the models' price instability comes about from supply shocks where the variation in supply is due to shifting supply curves. These assumptions have been criticized. To relax these assumptions, we introduce a price risk model that distinguishes between ex ante decisions and ex post outcomes, and supply shocks are generated not from a shift in the planning supply curve, but rather, from production deviations from it. Even when a price risk model is used, society prefers price stability to instability-the result common in the literature. Also, private competitive storage leads to optimal price stability and, therefore, there is no need for government storage.
\end{abstract}

\section{Keywords}

Commodity Stocks, Price Risk, Stabilization

\section{Introduction}

Society's preference for commodity price stability is supported by many researchers where price stability is generated through storage (Massell, 1969, 1970; Just et al., 1978, 2004; Konandreas \& Schmitz, 1978; Turnovsky, 1978; Gardner, 1979; Wright \& Williams, 1982; Tangermann, 2011; Schmitz \& Kennedy, 2016; Schmitz, 2018a, 2018b; Kennedy et al., 2019, 2020; McLintock, 2020; Schmitz \& Chegini, 2020; van Kooten et al., 2020; Schmitz et al., 2021). However, most of the models used to arrive at this conclusion assume that prices are known with certainty, and instability is generated by supply shocks where the variation in supply is due to shifting supply curves. These assumptions have been criticized (e.g., Tisdell, 1972; Just et al., 2004). To relax these assumptions, this paper introduces a price risk model that distinguishes between ex ante decisions and ex 
post outcomes. Producers are assumed to make production decisions using a planned supply curve. Supply shocks are generated from production deviations from the planned supply curve rather than from the shift in supply curves.

\section{Risk Framework}

In the risk models discussed below, it is made clear that price instability brought about by production shocks are not generated from shifts in supply curves, rather the instability is due to production variation from a producer's planned supply curve.

\subsection{No Price Instability}

Consider the following model framework that deals with price risk in later models. The framework is very different than used in standard stability models. Here, we separate ex ante decisions on the part of producers from ex post outcomes. In standard models, both price and quantities are known with certainty. As shown in Figure 1, demand is given by $D_{d}$, and $S_{p}$ is the producers' supply curve. The latter is an ex ante planning curve, where producers at planting time expect to receive price $p_{e}$ for their crop and expect to produce $q_{e}$. The area $\left(p_{e} b c\right)$ is the cost of the fixed factor of production, while area $\left(b q_{e} c\right)$ is the total variable cost. Therefore, the producers' expected total cost equals $\left(p_{e} b q_{e} c\right)$. The expected total revenue is $\left(p_{e} q_{e}\right)$.

\subsection{Price Instability under Zero Storage}

For simplicity, many conventional models use two time periods, where production in period 1 is very different from production in period 2. However, the outcomes (both prices and quantities) are known with certainty.

\subsubsection{Period 1}

Suppose in period 1 that due to abundant rainfall, output is $q_{1}$ that exceeds expected production $q_{e}$. The price falls from $p_{e}$ to $p_{1}$. In this case, total revenue (TR) is $\left(p_{1} b q_{1} d\right)$, while the total cost (TC) is $\left(p_{e} b q_{e} c\right)$. The effect on

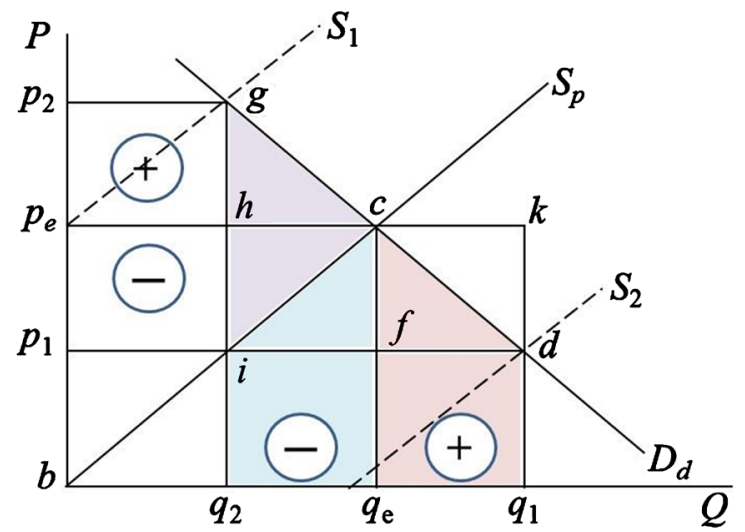

Figure 1. Price instability: Ex ante versus ex post outcomes. 
producers is negative $\left\{\left(p_{e} p_{1} f c\right)-\left(f q_{e} q_{1} d\right)\right\}$. The gain to consumers is $\left(p_{e} p_{1} d c\right)$. The net societal gain is $\left(c q_{e} q_{1} d\right)$.

\subsubsection{Period 2}

In period 2, due to drought, output falls to $q_{2}$ which is less than the expected output $q_{e}$. The price increases to $p_{2}$ which is above the expected price $p_{e}$. As a result, total revenue (TR) is $\left(p_{2} b q_{2} g\right)$, while TC remains at $\left(p_{e} b q_{e} c\right)$. The negative effect on producers is $\left\{\left(p_{2} p_{e} h g\right)-\left(h q_{2} q_{e} c\right)\right\}$. The loss to consumers totals $\left(p_{2} p_{e} c g\right)$. The net societal loss is $\left(g q_{2} q_{e} c\right)$.

\subsubsection{Periods 1 and 2 (Net Producer Loss)}

Over the two periods, there is a net loss to producers from a price variability of $2(h i f c)$ or $\left\{(h i f c)+\left(p_{e} p_{1} i h\right)\right\}$. There is a consumer gain of (cid).

The relative losses to producers from price risk depend on price demand elasticities. The more elastic the demand, the greater will be the loss in period 2 relative to period 1, but there remains a loss in each period. Also, under elastic demand, the producer loss is greater; therefore, it is in the interest of producers to use storage to create price stability.

\subsubsection{Periods 1 and 2 (Net Consumer Gains)}

In this model, consumers lose from price stability while producers gain. In period 1 , consumers gain $\left(p_{e} p_{1} d c\right)$ while, in period 2, they lose $\left(p_{2} p_{e} c g\right)$. On net, consumers lose (cid).

\subsubsection{Combined Effects of Price Instability}

In the absence of storage in period 1 , the net effect of price instability is $\left(c q_{e} q_{1} d\right)$ and for period $2\left(g q_{2} q_{e} c\right)$. The combined effect is $(g i c)$.

\subsection{Price Instability with Storage}

We now consider the effect of storage that is used to bring about price stability. Earlier models were incorrect in arguing that storage brings about complete price stability. In this framework, storage can only bring about partial price stability (Schmitz, 2018a). Under achievable storage, the price is completely stabilized.

When $\left(q_{e} q_{1}\right)$ is stored in the abundant supply period and released in the short supply period, price is stabilized at $p_{e}$. The effects are as follows:

$$
\begin{gathered}
\text { Producer gain from stabilization }=(h i f c)+(c f d k) \\
\text { Consumer loss from stabilization }=-\left(p_{2} p_{e} c g\right)+\left(p_{e} p_{1} d k\right)
\end{gathered}
$$

where $\left(p_{2} p_{e} c g\right)=(h i f c)$ and $\left(p_{e} p_{1} d k\right)=(c f d k)$.

$$
\text { Net gain from stabilization }(\mathrm{gic}) \text { is positive. }
$$

\section{Producer Gains from Storage: Different Demand Price Elasticities}

The incentive for producers to engage in storage depends on the nature of the 
product produced. Consider Figure 2, where demand $D^{*}$ is more price elastic than demand $D$. The producers' planned supply curve is $S_{p}$. The stable price and quantity are $p_{s}$ and $q_{s}$, respectively. Consider the effect in period 1 of a production shock of $\left(q_{s} q_{1}\right)$. For demand $D$, the price falls to $p_{4}$, but for $D^{*}$, the price falls to $p_{1}$ and the net loss in total revenue is $\left\{\left(p_{s} e q_{s} f\right)-\left(p_{4} e q_{1} c\right)\right\}$. Under demand $D^{*}$, the total revenue falls from $\left\{\left(p_{3} e q_{s} f\right)-\left(p_{1} e q_{1} d\right)\right\}$. Thus, for the more inelastic demand, the greater is the loss in total revenue from a supply shock.

Consider period 2. For demand $D$, a production shock of $\left(q_{2} q_{s}\right)$ causes price to increase to $p_{3}$, but for $D^{*}$, the price increases to $p_{2}$. Hence, under inelastic demand $D^{*}$ relative to $D$, total revenue increases by $\left(p_{2} p_{3} b a\right)$ for a production change of $\left(q_{2} q_{s}\right)$. Hence, the gain in total revenue for demand $D$ is smaller than for $D^{*}$. However, compared to period 1, the size of the loss in period 1 is far greater than the gain in period 2 under demand $D^{*}$ versus $D$ as measured by $\left\{\left(p_{4} p_{1} d c\right)-\left(p_{2} p_{3} b a\right)\right\}$. This adds to the incentive for producers to store when the commodity produced is relatively price inelastic.

\section{Conclusions and Limitations}

The major conclusion from our risk model supports the use of storage to improve society's welfare. This conclusion further supports that reached by other researchers who largely use models where production and price under different time periods are known with certainty.

Within our model, there is no need for government storage. To maximize profits, producers carry out storage. The incentive for producers to store increases when the price elasticity of demand for the commodity is highly inelastic.

The conclusion supporting private storage does not take into account the support for government storage to improve food security in food-deficit less-developed countries. If a government's objective is to use stocks to promote

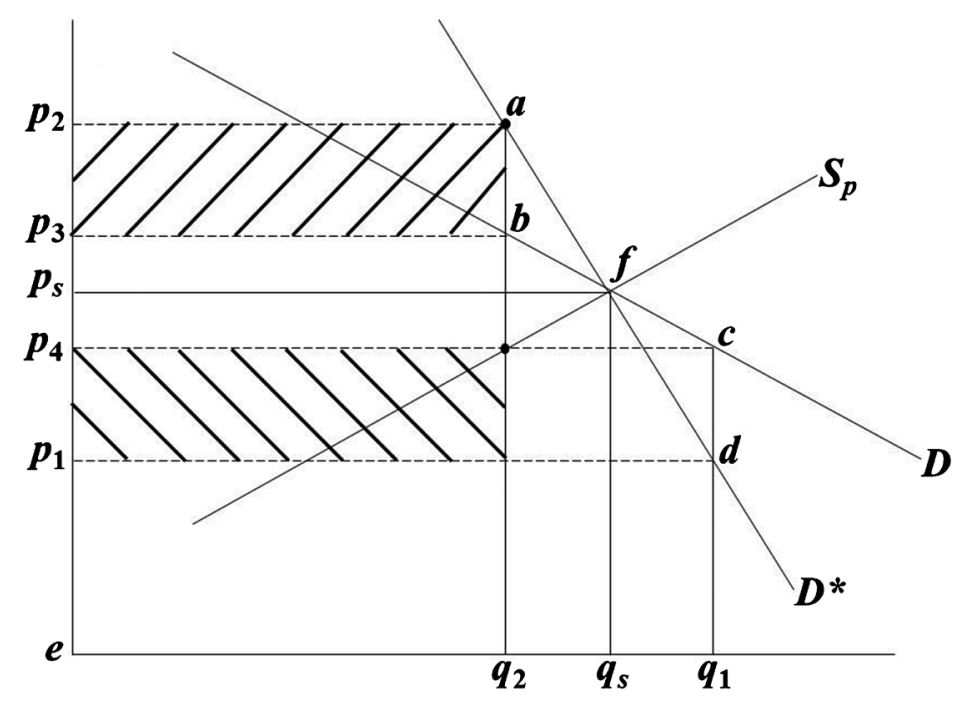

Figure 2. Producer storage under different demand price elasticities. 
food security, this may lead to a different outcome than producer profit maximization (Kennedy et al., 2019, 2020; van Kooten et al., 2020).

It is important to keep in mind that our model, like those of many other researchers, is based on classic welfare economics. Within this framework, the role of government to promote food security should be given explicit treatment. In addition, our model should be extended to include more than two time periods. For example, in a four-time period model, the results could be derived when probabilities attached to higher output periods are greater than those attached to lower output periods. Also, we do not consider producer supply response under rational expectations, a topic dealt with by Wright and Williams (1982). Under these conditions, the planning supply curve in our model could take different forms.

\section{Acknowledgments}

The comments from Professors Lynn Kennedy and Cornelius van Kooten, and three anonymous reviewers are greatly appreciated. Also, I thank Carol Fountain for editorial assistance.

\section{Conflicts of Interest}

The author declares no conflicts of interest regarding the publication of this paper.

\section{References}

Gardner, B. L. (1979). Optimal Stockpiling of Grain. Lexington Publishing.

Just, R. E., Hueth, D. O., \& Schmitz, A. (2004). The Welfare Economics of Public Policy: A Practical Approach to Project and Policy Evaluation. Elgar Publishing.

Just, R. E., Lutz, E., Schmitz, A., \& Turnovsky, S. (1978). The Distribution of Welfare Gains from Price Stabilization: An International Perspective. Journal of International Economics, 8, 551-563. https://doi.org/10.1016/0022-1996(87)90006-7

Kennedy, P. L., Schmitz, A., \& van Kooten, G. (2019). Food Security and Food Storage. Encyclopedia of Food Security and Sustainability, 2, 433-443. https://doi.org/10.1016/B978-0-08-100596-5.22251-8

Kennedy, P. L., Schmitz, A., \& van Kooten, G. C. (2020). The Role of Storage and Trade in Food Security: Evidence from India. Journal of Food and Industrial Organization, 18, Article ID: 20190056. https://doi.org/10.1515/jafio-2019-0056

Konandreas, P., \& Schmitz, A. (1978). Welfare Implications of Grain Price Stabilization: Some Empirical Evidence for the United States. American Journal of Agricultural Economics, 60, 74-84. https://doi.org/10.2307/1240163

Massell, B. F. (1969). Price Stabilization and Welfare. Quarterly Journal of Economics, 29, 284-298. https://doi.org/10.2307/1883084

Massell, B. F. (1970). Some Welfare Implications of International Price Stabilization. Journal of Political Economy, 78, 404-417. https://doi.org/10.1086/259637

McLintock, J. (2020). The Fight against Food Shortages and Surpluses: Perspectives of a Practitioner. CABI Publishing. 
Schmitz, A. (2018a). Commodity Price Stabilization under Unattainable Stocks. Theoretical Economic Letters, 8, 861-865. https://doi.org/10.4236/tel.2018.85061

Schmitz, A. (2018b). Producers' Preference for Price Instability? Theoretical Economic Letters, 8, 1746-1751. https://doi.org/10.4236/tel.2018.810114

Schmitz, A., \& Chegini, C. (2020). Producer's Preference for Price Instability: Revisited. Theoretical Economics Letters, 10, 1193-1197. https://doi.org/10.4236/tel.2020.105070

Schmitz, A., \& Kennedy, P. L. (2016). Food Security and the Role of Food Storage. In A. Schmitz, P. L. Kennedy, \& T. G. Schmitz (Eds.), Food Security in a Food Abundant World: An Individual Country Perspective (pp. 1-18). Emerald Group Publishing.

Schmitz, A., Moss, C. B., Schmitz, T. G., van Kooten, G. C., \& Schmitz, H. C. (2021, Forthcoming). Food and Agricultural Policies: Trade, Agribusiness, and Rent-Seeking Behaviour (3rd ed.).University of Toronto Press.

Tangermann, S. (2011). Policy Solutions to Agricultural Market Volatility: A Synthesis. Issue Paper No. 33, International Centre for Trade and Sustainable Development.

Tisdell, C. (1972). Some Circumstances in which Price Stabilisation by the Wool Commission Reduces Income. Australian Journal of Agricultural Economics, 16, 94-101. https://doi.org/10.1111/j.1467-8489.1972.tb00093.x

Turnovsky, S. J. (1978). The Distribution of Welfare Gains from Price Stabilization: A Survey of Some Theoretical Issues. In G. F. Adams, \& S. A. Klein (Eds.), Stabilizing World Commodity Markets (pp. 119-148). Lexington Publishing.

van Kooten, G. C., Schmitz, A., \& Kennedy, P. L. (2020). Is Commodity Storage an Option for Enhancing Food Security in Developing Countries? Journal of Food and Industrial Organization, 18, Article ID: 20190054.

https://doi.org/10.1515/jafio-2019-0054

Wright, B. D., \& Williams, J. C. (1982). The Economic Role of Commodity Storage. The Economic Journal, 92, 596-614. https://doi.org/10.2307/2232552 